\title{
Balancing the Books on Conservation and Development: Transient Corporate Investment in Golfito, Costa Rica
}

\author{
Jane W. Gibson
}

Golfito is a port town that stretches about three kilometers along the tiny bay from which it takes its name. This bay lies within the larger Golfo Dulce on the South Pacific coast of Costa Rica. Upon arrival by bus, descending to the coastal town through oil palm, banana, and gmelina plantations carved into the tropical rainforest, the sillouhettes of coconut palms frame the meeting of land and sea, creating a postcard image of tropical paradise. Yet this image, used to promote ecotourism in the area, is illusory according to the Instituto Costarricense de Acueductos y Alcantarillados (AyA), the Costa Rican institute for aquaducts and sewage systems. In 1997, AyA studied the environmental quality of 60 Costa Rican beach communities and found Golfito to be among the five most contaminated (La Nación`December 19, 1997:6A).

This paper, based on field research during the summer of 1995, and archival and internet research since then, develops a historical, political-ecological analysis to understand how this situation has come about and its implications for "sustainable development." These lenses show that environmental politics plus international and national inequality, particularly the uneven distribution of power and material resources for national development, explain how Golfito came to be offered up as "ecological sacrifice" in Costa Rica. The case suggests a pattern-Golfito is not unique in its environmental plight-in which some areas are protected in the interest of conservation while others are traded-off in the interest of "development." Opponents of environmental racism have argued against such policies as they affect minority and poor populations within nations. Here we see its global manifestation in the political and economic inequality between powerful corporations and developing nations, and between national and local governments which, together, exact social and environmental costs against disenfranchized communities.

Part I of the paper describes the history of Golfito as it is enmeshed in the relationship between U.S.-based United Fruit Company and the Costa Rican government. The section links micro-level social, economic, and environmental conditions, that is, human ecology, with national and international political economy. This history provides the setting for Part II, when global environmental politics began to shape public and private policies, particularly with regard to public images. Golfito's history from 1985 to the present involves two development strategies: construction of a tax-subsidized "mall" to promote domestic tourism, and construction of a chipper and shipping facility by Ston Forestal, another U.S.-based corporation. These strategies arose in the context of Costa Rica's national economic depression and international lenders' insistence on "structural adjustment." 
Part III of the paper discusses the environmental consequences of development in Golfito and on the Osa Peninsula, an area whose protection was won at Golfito's expense. These consequences are set in an investment environment favorable to transient foreign corporations for whom environmental damage is considered an externality. The paper concludes with an argument that Golfito's compromised economy and ecology are part of a pattern in which transient corporations' demands for profit, and government needs for debt relief and development revenue, conflict with national and international concerns for ecosystem conservation. What Redclift (1992) described as a fundamental contradiction in the notion of "sustainable development" is not resolved in Golfito, nor anywhere else that profit is used to measure development success; nor is it resolved on the protected Osa Peninsula where local needs for "development" were not considered. Instead, "sustainable development" is being finessed by geographical separation of the two agendas. Profitoriented investments continue apace in Golfito and in other vulnerable sites. Ecosystems are degraded in the process and while economies benefit in the short-run, but remain wholly dependent on transient outsiders. Through this case study, the paper examines the historical political ecology of transient corporate investments in developing countries, and it explores the following questions: To what extent do such investments constitute "development"? Does conservation in park systems protect fragile ecosystems? By separating development from conservation, does either model improve the well-being of resident peoples? Are such strategies "sustainable"?

\section{Part I. A Colonial Town History}

Scholars disagree with Golfiteños' historical account that nothing existed in the region before "the company." Precolombian artifacts have been unearthed in the Southern Pacific Region of Costa Rica, including the area around Golfito. Additionally, the 1910 census reported 2424 independent banana producers in the Brunca region ${ }^{1}$ (A. Cerdas 1993). Then, on the Atlantic Coast, the United Fruit Company began to experience the combined ecological problems of banana plantations (soil depletion and banana pathogens and predators : Sigatoka, a fungus, and Taltuza, a root-eating rodent) as well as labor "unrest" in the form of costly strikes. The company began to look for a solution to these problems in the Southern Pacific region of the country where they found fertile soils, a healthier climate, and an available labor supply. In 1934, the company acquired 118,000 hectares of land, about $12 \%$ of the Brunca Region. On the edge of the deep water harbor, above which rose near-vertical, rainforested hills, they blasted and bulldozed shelves for construction of roads, office buildings, houses, and the singularly indispensable muelle (dock) from which bananas would be loaded. Bananas first left the new dock in Golfito in 1941 (d. luckey 1994).

Golfito's history can thus be seen as part of U.S. history, and the town proper as a colonial town. From the 17th through the 19th centuries, U.S. history records a continually expanding frontier in which process North American civilians and soldiers occupied others' lands and exercised military control over surviving Indian populations. This stage ended about 1890, at the end of the first Industrial Revolution, when for the first

1. The Brunca region encompasses the South Pacific Region of Costa Rica made up of six cantons or administrative areas, covering 954,270 hectares including the Province of San Josè. Thus, population figures for the region are not comparable to population figures for Golfito. 
time the U.S. had acquired a capital surplus that increased demand for markets overseas. In short, American capitalists needed to expand beyond national boundaries at the exact moment when they had the resources to do so: money and the support of a government dominated by industry and finance. Kepner and Soothill wrote,

It was natural that we should first turn to Latin America, justifying our action in official rhetoric on the ground of advancing the cause of human justice, but not failing in the process to increase the facilities for investment and to acquire under favorable conditions the valuable natural resources of the lands occupied (C.

Kepner, and J. Soothill 1935:16).

Costa Rica began its incorporation into the world market before declaring its independence from Spain in 1821. By 1760, tobacco was being exported to Nicaragua and Panama; after 1830, coffee became the most important export crop. Through the consolidation of agrarian capitalism, Costa Rica's internal economic, political, and social structures were transformed, and the country became vulnerable to fluctuations in the international market (Solís 1998). From 1850 to 1890, coffee represented $90 \%$ of total exports (Acuña and Molina 1991), and its production covered the central valley, increasing the country's dependence on imported goods and decreasing the size of the internal market. At the same time, transportation was improved with a road to Puntarenas built in the 1840s and the railroad's completion to the Atlantic Coast in 1895. With construction of the Port of Limón, colonization of the region escalated, and banana and cocoa production changed the export economy. The period between 1871 and 1914 saw significant economic growth stimulated in large measure by a massive infusion of foreign capital.

In 1899, four banana export companies-the Boston Fruit Company and three companies owned by Minor C. Keith-merged to form the United Fruit Company. Even among Central American nations, the United Fruit-Costa Rican government relationship stands out as somewhat exceptional. In particular, the company negotiated directly with the Costa Rican government as one sovereign to another and, as discussed below, consistently won concessions for the company at the expense of Costa Rican citizens. This relationship was secured before the company was ever incorporated when Keith, an American railroad builder, married the daughter of former Costa Rican President José María Castro. The country had suffered financially, and resources were unavailable to contribute to the great patriotic dream: completion of the railway connection from the Central Railway to the Atlantic. Keith agreed to help with both financial and infrastructural problems in exchange for "privileges which made him the dominant force in railroading, governmental finance, and the development of the banana industry" (C. Kepner and J. Soothill 1935: 44).

For the first several decades of United Fruit's existence, the government consistently favored the company over its competitors, over Costa Rican banana producers and workers, and seemingly over the short and long-term national interest. For example, in 1907, President Cleto González Víquez vetoed one of a number of attempts to secure some return to the government from the export of bananas. He declared that a levy would be an infringement of the rights of the United Fruit Company under the 1900 contract. Then, in 1910, when that ten-year exemption period had expired, Congress imposed an export tax of one cent per bunch of bananas for a twenty-year period, at the same time binding the state not to add any other tax, national or municipal, even though it might be considered a charge for such national service as wharfage (ibid:78). A two-cents-per-bunch tax was proposed for the 1930 twenty-year contract, but was dropped after heated debates. 
Instead, a sliding-scale export tax law was approved in 1929 that, for the first time, protected Costa Rican banana producers, whether or not they were under contract to United Fruit. However, Congress overturned the law before it went into effect after the company initiated a public relations campaign that contained thinly veiled threats to take its business elsewhere. Congress replaced it with a two cents-per-bunch export tax and a provision guaranteeing that no other tax would be imposed on the banana industry.

The new law also exempted the company from all wharfage charges or import duties, and it permitted United Fruit to build a port and wharf on the Golfo Dulce on the Pacific Coast should the government itself fail to do so within five years. The company already had the right to build railroads anywhere it chose, and it had begun acquiring Pacific Coast land before 1930. In response to the contract, editorialist Joaquín García Monge published his concerns in El Repertorio Americano :

At present the opposition to the proposed contract is due to the fear that the United Fruit Company will dominate the Pacific as it has the Atlantic coast, where it now controls the railroad, the wharf and ocean routes, and dominates the lands and the district of Limón (quoted in C. Kepner and J. Soothill 1935:82).

When the company moved to Golfito, some 33,000 laborers migrated there in search of work. Among them were those who would work in the banana plantations, those who would work as loaders on the muelle, and skilled workers such as machinists and carpenters. Entrepreneurs also came to take advantage of the market for such services as restaurants, bars, and clothing stores. Apart from the small "Pueblo Civil" where these businesses opened their doors, la Compañia Bananera provided all things needed by their workers: housing, food, yard work, plumbing, electrical repair, and other basic requirements.

The social structure of the company was reflected in the town's physical layout. At the northern end of the town, an area known locally as the Barrio Americano, but on maps as Barrio Alamedas, the company built large houses with expansive yards for their administrators. They put in septic tanks, a swimming pool, tennis court, golf course, and a water chlorinator. At the southern extreme of the town, the poorest Golfiteños live in a barrio known by its nickname "Hong Kong." These residents include fishermen and shrimpers who built their own houses on stilts that keep them dry at high tide. Houses share walls and walkways so that one must pass through those on the beach to reach those farthest out over the bay. Between these two extremes, the company built houses for their employees: small and closely spaced houses for skilled workers, and still smaller and still more closely spaced houses for unskilled workers.

Employees' families living in the central and southern parts of town depend on untreated groundwater $^{2}$ for cooking,washing, and drinking. With the exception of fish caught and sold by local artisanal fishermen, food is imported to Golfito and sold in one of three markets: the oldest Mercado Golfito; a modern supermarket that is part of a national chain; and an open-air market to which farmers from the region bring their produce to sell on Saturdays. Today, a family may grow a few herbs and closely spaced fruit trees, and a few maize plants and fruit trees grow on the narrow shelf between the main road and the bay. In a few places, residents have cut away the vegetation on the steep slope behind their

2. Water quality in Golfito is widely believed to be very good though no tests have been carried out. 
barrio, and sugar cane, banana, and a few other food plants cling precariously to the "wall."

Near the center of the three kilometer stretch of Golfito's main road is the Pueblo Civil where bars, restaurants, and different kinds of shops are concentrated. The city government and post office also have offices in the Pueblo Civil around which neighborhoods have grown up. A cemetery further south along the road contains graves dating from the 1930s, attesting to the full spectrum of life and death which occurred under the company's jurisdiction. The following excerpts reflect commonly held views in Golfito (fieldnotes 1995).

The company built this town. There wasn't anything here before the company. They came over from the Atlantic Coast and decided to build the dock here. Without that dock, this town wouldn't be anything. They brought in heavy equipment and built the road and the houses. And they built the hospital and later some schools. If it weren't for the company, there wouldn't even be a town here.

Everybody worked for the company. They had people working the docks, loading bananas, and they had mechanics and carpenters and other maintenance people, and of course there were administrators. They all lived up there [the northern part of town].

The company did everything for everyone. Mamita Yunaí, you know. They gave everyone a house and an income and they did everything for them. If you needed your plumbing repaired, you'd just call them to come and repair it and they'd send someone. If you needed your lawn cut, they'd send someone to do that. If a lightbulb burned out, they'd send someone to change it.

When banana prices on the world market began to fall in the 1970s, and problems of labor unrest on the part of plantation workers followed United Fruit to the Pacific Coast, the company announced in 1981 that it would pull up stakes in Golfito and "deemphasize" its influence in the area. Though their wages were relatively high, plantation workers felt exploited by the company because local administrators continually exerted downward pressure on wages to satisfy their bosses in the US. Additionally, plantation workers were frequently poisoned by chemicals used to protect the bananas from insects and disease. The hospital in Golfito reports that the number one problem they saw during the company's tenure was work-related accidents, poisonings being the most common among these (pers. comm.).

Yet urban Golfiteños who worked on the dock and in more skilled positions, as their comments above show, did not share the dissatisfaction of plantation workers. Young boys fully expected to work for the company when they grew up, and for them and their families, the company presence meant a stable and predictable income as well as a relatively good quality of life. Hay, writing in 1983, sympathetically characterized the history of the company as "one of modernization, change, adaptation and even reconciliation, as shifting political and economic circumstances have dictated." But with the devastating news of its departure from Golfito, he also wrote:

...with the virtual disappearance of Costa Rica's virgin territories and ever more pressing needs for new agricultural lands, [Golfito] will not simply be depopulated and abandoned. What then, will be the legacy of the Bananera?...Most importantly, though, what will be left in terms of human resources? After forty years under the economic and social umbrella of the company, it would be well to question how the population is equipped, in a number of ways, to live as a full and productive society... (Hay 1983). 
The company began to withdraw its corporate offices from the town and to divest itself of other investments in the region. They also began to shift banana production to other locations, mostly in other countries, and to plant their Costa Rican plantations with African Oil Palm, a crop which requires substantially less labor. By 1985, the company completed its evacuation, and Golfiteños today, more than a decade later, carry on with their lives which, in their own telling, are still shaped by the activities of the United Fruit Company, the Mamíta Yunaí (C. Fallas 1970). Among the ways the company maintains its "presence" in Golfito are the economic desperation and the environmental damage it left behind.

\section{Part II. Local and National Survival Strategies}

Costa Rica, like every other country in Latin America, has suffered in recent years from an economic crisis of new proportions. The national debt rose to $\notin 795,080$ million in December of 1996 (La Nación 1996), and the government continued to respond with its push to privatize national services and industries. The plan included the sale of Banco de Costa Rica (BCR), Radiográfica Costarricense S.A. (RACSA), el Banco Internacional de Costa Rica (BICSA), the Instituto Nacional de Seguros (INS), and some of Costa Rica's valuable beachfront. According to preliminary estimates by the UN's Economic Commission for Latin America and the Caribbean, Costa Rica slipped from recession into depression during 1996, faring the worst among the six Central American nations.

A series of factors contributed to the crisis, including poor world coffee prices (coffee is Costa Rica's number one export today), plus adverse weather conditions, which destroyed agricultural crops in July and August. In addition, government efforts to control inflation-which succeeded in reducing the consumer price index from $22.5 \%$ in 1995 to $14 \%$ in 1996-in turn worsened the economic slowdown. High interest rates, combined with an increase in the value-added tax and other levies, depressed investment and consumer demand (Latin America Data Base 1997).

These figures reflect the most difficult year in Costa Rica's economic crisis since the early 1980s, and when United Fruit pulled out of Golfito in 1985, national resources for economic rescue were already in painfully short supply. The country's main strategies included privatization and austerity coupled with the promotion of tourism, particularly ecotourism, a strategy that purports to balance local and national needs for development revenue with global demands for environmental conservation. The national government, through its Instituto Costariccense de Turismo (ICT), offered another kind of tourism to rescue Golfito. Whereas parks and preserves courted international tourists, Golfito's new Depósito Libre would attract national ones. The Depósito is a large outdoor mall where Costa Rican citizens (and expatriate visitors) can shop twice per year and spend up to $\$ 400$ each time. Taxes are subsidized to reduce the costs of electrodomésticos (refrigerators, televisions, radios, washers, dryers, and other appliances) and other consumer goods to buyers. Of the revenue generated, "up to $25 \%$ " is earmarked for tourist development in Golfito.

Since 1994, the growth of international tourism revenue to the country has declined, and promotion by the ICT of national tourism was designed to take up some of that slack. Yet this strategy has met with only modest success in part because Costa Rican tourists spend much less than the average US $\$ 90$ per day spent by foreign visitors (Latin American Data Base 1997). Given the town's ecological status, the promise of money to develop 
ecotourism in Golfito can only be regarded as a cynical gesture. Indeed, in an opportunistic sample of seated visitors to the Depósito, no one surveyed stayed even the required minimum two nights in the town, and the only expenditures made outside the mall were for minimal accomodations and food.

The phrase "up to $25 \%$ " provides a loophole that allows revenue to be diverted elsewhere, and indeed the Depósito has yet to provide the municipality with the full $25 \%$. What little has been received is earmarked for tourism development as required, and a road has been built between Golfito and Playa Cacao. This road carries visitors by bus and taxi to the small beach whose few bars and hotels face the dock built by United Fruit and, behind it, urban Golfito. The beach and its properties, like others around the bay, are owned primarily by expatriates who have bought up ocean-front property and thereby driven land prices out of the reach of most Costa Ricans. But even well-to-do expatriates cannot benefit from the Depósito's tourism revenue so long as the bay continues to serve as the primary solution to solid waste and sewage disposal.

It is impossible to estimate the direct effects of the Depósito on employment and income because of turnovers in concessions and employees, and because Golfiteños have concentrated on informal sector investments. Yet all agree the Depósito has been beneficial to Golfiteños. Outside the shops, between 150 and 200 perreros move heavy merchandise with their own or rented dollies for between $₫ 200-\phi 250$ per load. They are formally organized and contribute to a central pool which pays for any damages should, for example, a perrero drop a refrigerator. Though no Golfiteño owns a concession in the Deposito, based on interviews with 26 employees, including 13 store employees and 13 perreros, Golfiteños hold over $73 \%$ of the jobs available. Three people relocated to Golfito permanently in order to find work, and the rest commute from areas within the region.

Outside the Depòsito, many small-scale entrepreneurs carry on business with national shoppers. Among them are organized tarjeteros, people who act as brokers between those who want to sell their rights to buy $\$ 400$ worth of merchandise and those who want to spend more than their allotment. Also, on any day 25-30 kiosks open their windows to sell a wide variety of commodities including music cassettes, canned food, and doll clothes, and at least ten freestanding tables occupy sellers of watches and sunglasses brought in from Panama. Seated among these are fruit and vegetable vendors from the rural parts of the region where farming is still possible. Mobile vendors sell empañadas and snowcones from their wheeled carts. All of these people, with the exception of the fruit and vegetable vendors, live in Golfito. Collectively they constitute the growing informal sector reviled by the Costa Rica Chamber of Commerce whose president defined these small-scale entrepreneurs as those unqualified to run businesses, and whose irregular business practices impede control and regulation (La Republica, April 14, 1994:12A).

Around the periphery of the Depósito, other businesses flourish. As of the summer of 1995, 51 cabinas and hotels accomodated overnight visitors, and virtually all were built to take advantage of the influx of visitors to the Depósito. Indeed, $100 \%$ of the cabinas in Golfito, and all hotels north of the center of the town near the dock were built in direct response to its presence. Across the street alone, 26 sodas $^{3}$ and restaurants operate, and many other food service businesses have opened up in the barrios closest to the rotonda,

3. "Sodas" are similar to refreshment stands Americans find at some sporting events. 
the area where the Depòsito is located. The distribution of these, like those of the cabinas and hotels, diminishes as one moves south.

Other signs of Golfito's economic recovery include the three hardware stores or ferreterìas which sell everything one needs to build, repair, or remodel a house. The "Josefino" 4 owner of the shop that supplied the needs for construction of the Depòsito is said by locals to have become a millionaire. Two others meet the construction needs of many houses, new cabinas, and soda expansion. Significant social changes are also reflected by construction of a daycare center-because young mothers have gone to work, and a retirement home- because grown children are less available to care for their elderly parents.

In short, the Depósito Libre has dramatically stimulated Golfito's economy, though in some ways unforeseen and unappreciated in San José. Costa Ricans do come to shop in Golfito, some 600,000 in 1994. The Depósito also helps to solve some of the government's own economic problems. Not only is the Depósito meant to rescue Golfito; it is also the government's Pacific Coast answer to cheap goods sold just across the Panamanian border. Golfito, it is hoped, can help stop this financial leak.

The Costa Rican government has also encouraged another multinational corporation to invest in Golfito. Ston Forestal is a wholly-owned subsidiary of Stone Container Corporation of Chicago, Illinois. According to the company (Ston Forestal 1997a), Ston Forestal's main responsibilities include the planting, growing, forestry management, harvesting, chipping, and exporting of a tropical hardwood called gmelina. The chipped product exported from Costa Rica will ultimately be converted into printing and writing papers, high softness tissue, release papers, photographic papers, and calendered papers for wrapping (Ston Forestal 1997c). Gmelina is native to southern and southeast Asia and has been widely introduced into the tropical climates of Africa, Central America, South America, and Asia. Genetically engineered seedlings grow rapidly and are harvested in the sixth year at 18 meters (Ston Forestal 1997d).

Ston Forestal's Costa Rican project began in 1989 with the purchase and planting of a 1000 hectare cattle ranch, located between the towns of Palmar Sur and Rio Claro along the Pan-American Highway. This site, known as the Salama Farm, accomplished three objectives: a) it provided the company a complete operations base with offices, guest facilities, and housing for administrative personnel; b) it contained enough land to demonstrate the company's forestry techniques (planting, harvesting, then replanting); and c) "the ownership and management of the land provided Ston Forestal with credibility and identity when leasing plantation sites from local landowners" (Ston Forestal 1997b).

Ston owns no other land in Costa Rica for both political and economic reasons. Indeed the company already leases plots between 8 and 350+ hectares from over 200 farms, and it plans to plant a total of 24,000 hectares of gmelina in support of the chipping and exportation of 600,000 green metric tons of gmelina chips each year. The company has planted over 13,000,000 gmelina trees to date. Leases do not include land occupied by primary forest, and consist mostly of lands previously used by local landowners for pasture and rice production (Ston Forestal 1997e). The large majority, over 90\%, lease land for 18 years thereby allowing Ston Forestal to complete three full growing/harvesting cycles. (Ston Forestal 1997f)

4. This man moved from San Jose to Golfito and opened up his ferreterìa specifically to supply the Depòsito. 
Ston plans to build its chipping and port facilities, the last components necessary to export gmelina, in Golfito. The company says it is cognizant of the environmental concerns related to the Golfito Site, though none of these is specified, and it highlights completion of "an extensive Environmental Impact Study," carried out by "a highly qualified team of experts," and submitted to the Government of Costa Rica for approval. The company expected to begin shipping by early 1998 (pers. comm.).

\section{Part III. The Environmental Costs of Development}

AyA's evaluation (La Nación December 19, 1997:6A) ranked 60 Costa Rican coastal communities on a hundred point scale with $>90$ earning "Class A" designation. The scale weighted ocean water quality $(40 \%)$, drinking water quality $(15 \%)$, beach cleanliness (trash - 10\%; brown waters - 15\%, industrial waste water - 10\%), safety (5\%), and education and administration (5\%). Golfito was designated "Class E", the lowest possible ranking, and received a total of 46 points out of the 100 possible. The brief description that follows explains this evaluation.

Golfito's bay receives untreated human waste pumped directly into it through pipes that connect houses to ocean. There the tide flushes the contents of the inner bay into the outer one. This "dilution solution" to urban sewage disposal contaminates the fishery on which artisanal fishermen depend. Bay contamination is further compounded by the infusion of solid wastes: everything from paper cups to plastic bottles to rubber tires. That which is not thrown in directly washes into the basin via creeks and concrete drainage canals where households daily toss their refuse. At low tide, one can see the abundance of garbage distributed underneath Hong Kong's wooden walkways that connect houses to each other and ultimately to the land.

Washing garbage out to sea is only one solution to Golfito's solid waste disposal needs. Others include burning and placement in bins, some neatly stenciled with the words "El Mejor Precio-Limpieza, Salud, Bienestar:" The Best Reward-Cleanliness, Health, and Well-being. The town owns trucks to pick up and dispose of waste, whose abundance in and around the bins tells of both local sympathy with the clean-up campaign as well as inadequate funding on the part of the Municipality to make pickups happen with necessary frequency. Litter and food waste attract legally protected zopilotes, Costa Rica's large avian, carrion-eating recyclers. To the north and out of sight of the main urban settlement, a growing and thriving zopilote population feeds on the town's open dump where solid waste piles up and spreads out in an open field just off the road. No data exist on the potentially more serious problem that toxic waste may move through the soil and into the bay. Leaching may also result from pools of petroleum lubricants that leak from rusting freight cars, abandoned and clustered above the bay.

Municipal leaders and residents acknowledge bay contamination, but leaders say there is no money in the budget for clean-up. Since most of the town gets its income and food elsewhere, only some need worry about this issue. A study carried out in 1985 found 108 licensed fishermen and an additional estimated population, including piangüeros (those who dive for mussels or clams), salaried fishermen, and fish vendors (mostly women), estimated at between 2000 and 2500 people dependent all or in part on artisanal fishing (M. Bozzoli and M. Chàvez 1987). These are the poorest Golfiteños who, if estimates are correct, constitute roughly $20 \%$ of the urban population. Because they are the poorest, they are also the least influential and will ultimately bear the full cost of bay contamination. Visitors are advised by word of mouth not to eat the fish from the bay, 
though fish are still sold from ice chests to local individuals and restaurants, and constitute an important part of many families' diets and budgets.

While the potential for long-term health consequences garners little attention locally, a more immediate problem does concern Golfiteños. United Fruit erected communications towers on the hills above the town, and to do so, they cut a road into the near vertical, rainforested slope. As in many tropical ecosystems, vegetation holds soil in place with shallow root systems; this makes slopes particularly vulnerable to erosion, mudslides, and landslides when the vegetation is cleared for any reason: farming, housing construction, or roads for example. United Fruit's road has contributed to a number of landslides when the soil surface has broken free of its substratum, sending tons of earth and vegetation thundering down on the houses below.

By constructing such communities, United Fruit assumed the responsibilities of government to provide for the general welfare, but unlike the motivations of government in civil society, the company's provision of infrastructure, employment, and social services served the interests of the company first, when not exclusively. For example, United Fruit deducted a percentage of workers' wages to pay for the construction of hospitals indicating that the company thought workers should bear the costs of treatment for pesticide poisoning. ${ }^{5}$ This view of occupational hazards as external to the costs of doing business is consistent with the company's adoption of short-term, cost-effective solutions to the problems of community construction. When the relationship ceased to be profitable, the company moved on.

It is both ironic and tragic that the success of the Depósito Libre should also bring with it an intensification of those very problems created by United Fruit in its construction of the town. More visitors mean more money for families in Golfito, but they also mean more brown waters and solid waste without a commensurate investment in treatment and disposal. Even if the ICT turned over to the municipality the full $25 \%$ of the Depósito's annual revenue, municipal leaders explain that none of that money could be spent for the environmental cleanup necessary to make tourist investment meaningful. Because about $80 \%$ of Golfiteños depend on wage labor, sales of imported commodities, and consumption of imported food, pressure on municipal leaders to invest in bay cleanup will likely remain at a minimum.

Nor should one expect either the struggling Costa Rican government, whose resources are diminished by national depression and structural adjustment requirements, or Ston Forestal, the latest multi-national investor, to channel clean-up assistance to the town. Ston Forestal says Costa Rica was chosen for its political stability, forestry laws, and favorable climate; the Golfito site was selected for several reasons:

Close proximity to Golfo Dulce (Pacific Ocean Access) and deep water shipping; close proximity to major plantation areas; and a favorable relationship with the people of Golfito, which will result in many local jobs, an improved economy, and improved infrastructure. (Ston Forestal 1997g)

Gmelina production has raised a number of concerns in Costa Rica, in part because Ston Forestal was forced out of Honduras by environmentalists worried about forest destruction. In response, the company redefined its Costa Rican project as "reforestation" of deforested lands. In this campaign, the company is cast in opposition to those

5. Golfito's medical facility was made available only to company employees until 1976, when a national law required that health care be provided universally. 
responsible for deforestation: poor managers, fuelwood extractors, hunters who burn areas to flush out game, and others who clear land for other uses (see J. Cook 1992). Omitted from company public relations reports is any mention of environmental concerns raised in Honduras, and its earlier attempts to locate the chipper and port on the Osa Peninsula at Punta Estrellas in the Los Mogos forest, a corridor between protected Corcovado and Esquinas National Parks. The latter proposal was rejected by the Costa Rican government after the environmental impact assessment noted the potential for ecological damage to both terrestrial and marine ecosystems, and economic damage to Costa Rica's ecotourist industry on the Osa peninsula (J. Zürcher de Carrillo 1994).

The following is a brief summary of the Environmental Impact Assessment. ${ }^{6}$

1) After gmelina is harvested, other species cannot succeed in its place because gmelina severely reduces soil nutrients.

2) Monocultures alter food chains and simplify species diversity.

3) Noise resulting from the transport of gmelina by 184 trucks every day, and from the chipper plant itself, will be sufficient to affect intraspecies communication and disrupt the natural behaviors of wildlife.

4) The protected region operates as a biological corredor which the plant would interrupt.

5) The plant would limit the development of other activities such as ecotourism in the fragile area.

6) Dumping of slurry into the bay will promote bacterial growth and threaten marine life.

7) The project will not generate significant employment and promises of training small farmers to produce gmelina will not affect more than a few. Subsistence farming has all but disappeared, and under the influence of the Compañia Bananera, farmers divided up their land and sold it. What remains as the dominant trend is tenancy, a model that will benefit Ston, but not Costa Rica. Insufficient information exists, and no studies, to say with confidence how Ston's model of renting parcels will affect small producers socioeconomically.

8) Sedimentation from road construction to the plant and dock will have an important impact on the ecology of the Golfo Dulce and of the Osa Peninsula in general.

9) Ston's conduct in the US, according to The Rainforest Action Network, has not been reputable in the areas of environmental law and security of employment.

In light of this report, Ston Forestal's special relationship with Golfito takes on new meaning. Costa Rica's need for export revenue has not diminished since United Fruit pulled out, and ecotourism still offers hope at reconciling its desperate need for revenue with conservation of fragile, life-sustaining ecosystems. To protect the environment and ecotourist development on the Osa Peninsula, without risking export revenue promised by Ston Forestal, Golfito-already environmentally compromised and economically vulnerable-was recommended by the Costa Rican government for Ston's chipper.

When asked about Ston Forestal's future in Golfito, community leaders expressed no real concern, though they did not believe the company would provide employment, contrary to company claims, unless the company were to follow through with a proposed

6. Four members of the team responsible for producing this assessment have since died: the ecologist in charge, and three others, together, in a fire. The new ecologist on the team supports Ston Forestal's gmelina operations. 
toothpick and popsicle stick factory that would employ some Golfito women. As to environmental damage, no community leader acknowledged the possible worsening of bay contamination from the chipper's slurry. Though the earlier environmental impact assessment resulted in cancellation of the company's original plans, the only environmental issue raised by two Golfiteño leaders concerned chipper noise which both likened to that of a typewriter.

\section{Discussion}

"Sustainable development" is an idealized approach built from the hope that humanity can find ways to meet its present needs without compromising those of future generations (WCED 1987). What the case study presented here implies is the potential to use "sustainable development," and other "green" language, as a rhetorical device that permits "development" to proceed apace, unmitigated by environmental concerns, at least where development investments are made. To paraphrase the questions raised earlier, when investments are made by transient private corporations, do these investments constitute "development"? And, if the books are balanced between development and conservation, is conservation, implemented with little or no incorporation of local development initiatives, sustainable?

For the Costa Rican nation, the answer to the first question is "yes and no." That is, Costa Rica enjoys a high standard of living relative to that of other Central American nations, but multinational corporate investments such as that of United Fruit and Ston Forestal are only partly responsible. Costa Rica's modernization benefitted significantly from social reforms initiated by political leaders such as Rafael Calderón and José Figueres. Between 1940 and 1944, Calderón instituted minimum wage regulations, restricted the number of hours women and children could be required to work, and provided medical and unemployment insurance, retirement benefits, severance pay, and maternity leave. He also reopened the University of Costa Rica, a move that promoted professionalization of many who would contribute to growth of the country's Welfare State (Salazar and Salazar 1991).

President José Figueres contributed what has probably been the most important political-economic maneuvers in the country's recent history when he abolished the armed forces, created a nationalized banking system, created a non-partisan Tribunal of Elections, and enacted a 10\% tax on large capital investments. With these two presidents' reform agendas, the country's middle class grew and became more politically active, especially as access to public education was extended widely, and demilitarization freed significant revenue for significant social programs. "The specialization of bureaucracy, the decentralization of State institutions, and most importantly, the creation of a very powerful Welfare State based upon the provision of health, education and housing services, were truly pivotal for the development of democracy in Costa Rican society" (Solís 1998). Costa Rica's development was shaped by its historic involvement with and commitment to foreign investors, but also by political reforms that promoted wider distribution of the benefits of economic growth. Through an era of mercantilist development into the 1950s, a period of import substitution during the 1960s and 1970s, "state entrepreneurship" until 1980, and export promotion coupled with import incentives until 1992, aggregate statistics show Costa Rica fared quite well. Indeed, economic growth has been steady since the 1950s, with the exception of recent crises. 
Between 1970 and 1989, annual accounts show a continuous rise in national income and a high rate of capital formation. Population increased from 280,000 at the turn of the century to 3.029 million in 1990; child mortality dropped from 192/1000 births between 1908-1912, to 14/1000 births between 1988-1992; and life expectancy among Costa Ricans increased from 41 in 1927 to 75 in 1993 (Solis 1998). Thus, Costa Rica is often regarded as an exception among Central American nations. Yet aggregate statistics such as these cannot explain phenomena related to the country's recent economic crisis for which the World Bank and the International Monetary Fund prescribed "structural adjustment" in 1992. Nor can they explain what they hide: the inequitable distribution of benefits among Costa Rican citizens.

About $35 \%$ of Costa Ricans live below the poverty line, and in depressed areas such as Golfito, these figures have been much higher in the last decade. While national tourism has induced a floresence of the town's informal sector and incomes have risen, the "good business" policies of United Fruit show how development based on foreign investment sets up a level of vulnerability that can result in catastrophe when the private sector employer shifts to a more profitable area or product. It also shows how accounting practices ignore environmental costs.

Depreciation of natural resources has been estimated for Costa Rica, and this value has been used to adjust the rate of capital formation in the national accounts system. The Tropical Science Center (TSC) and the World Resources Institute (WRI) published their collaborative study in 1991 as a policy decision-making tool that would correct for the flaws in traditional national accounting. These flaws included that only market transactions were counted; deterioration of the resource base and environmental quality were excluded; and environmentally destructive activities were counted as productive ones. The TSC/WRI study measured physical deterioration of forest, soils, and fisheries and concluded that, between 1970 and 1989, depreciation in real terms was equivalent to nearly the total value of GDP in 1984. This finding reflects an almost 5\% annual loss of GDP (Solórzano et al. 1991). Though the study is debated, particularly with regard to its methods (Celis 1998), it highlights the way traditional measures of development success omit environmental costs. It also requires that in our evaluation of development success, we ask for whom development is intended, and by whom will its costs be paid.

The benefits of United Fruit's investments in Costa Rica in general and in Golfito in particular are undeniable. In spite of the company's "good business" practices that took advantage of the country's political and economic vulnerability, the development of infrastructure and generation of income contributed to the prosperity of many. But because the company, a foreign capitalist investor, is necessarily transient as its profit motive dictates, benefits were not "sustained" in any location. And because environmental damage did not cost the transient private company anything, yet continues to exact a cost against Costa Rica's marine and terrestrial ecosystems, such development cannot be considered "sustainable." Today, as Ston Forestal gears up to make its contribution to Golfito's deep water harbor, we must ask if the protection of the Osa Peninsula balances the conservation and development books.

John Burnette, for National Public Radio, reported on the status of Corcovado National Park (NPR, October 13 and 14, 1997). Burnette interviewed Julio Calvo, director of the Tropical Science Center in San Jose, who said, "It's true we're preserving natural forest, but it's also true that we have not been able to stop deforestation, or the pollution of our rivers." According to Burnette's report, Osa contains one of the largest expanses of lowland tropical forests left in Central America, but all around its perimeter, the watershed 
is being clearcut and the resulting sedimentation is killing the last coral reef in the Golfo Dulce. Within the protected area, trees are also cut both illegally and legally. Private landowners are permitted to cut their own timber and, some small landowners say cutting is essential for survival. As one man put it, "We have to sell a little wood to survive. Let me tell you something, mister: the monkeys can eat fruit. But human beings can't. We have more needs." (ibid.)

The most significant policy instrument for protection of Costa Rica's biodiversity is its extensive system of protected areas. The Ministerio de Recursos Naturales, Energía, y Minas (MIRENEM) estimated that, by the end of 1990, around $28 \%(13,840 \mathrm{~km} 2)$ of Costa Rica's territory was legally protected. Another $0.4 \%(130 \mathrm{~km} 2)$ was in private reserves and about 10,000 $\mathrm{km} 2$ was forested, including production forest (MIRENEM 1990). Depending on the area's designation, the level of protection varies from complete proscription of consumptive uses (9\%) such as wood harvesting and hunting, to multipleuse management (12\%) including logging. In practice, however, protection is constrained by private ownership of $12 \%(560 \mathrm{~km} 2)$ of areas with complete legal protection and an even greater percentage of other categories.

Deforestation in Costa Rica occurs at a rate of 300 to $500 \mathrm{~km} 2$ per year, among the highest rates in Central America. ${ }^{7}$ In the 1940 s, about $70 \%$ of the mainland was forested; by 1990 , the figure was under 30\% (MIRENEM 1990). Causes are multiple and debated as to their relative weights, but recognized sources include such economic incentives as colonization in the search for land, commercial logging, and expansion of pasture for cattle (Celis 1998). Consequences of deforestation include loss of biodiversity, soil erosion, and sedimentation of estuaries, rivers, and other natural water systems. However, the most immediate harm is the loss of the wood itself for both industrial and fuelwood uses. According to an estimate by the Dirección General Forestal (DGF), by 1995, when most of Costa Rica's productive forest resources were projected to have been exhausted, Costa Rica would have to import \$200 million (U.S.) per year in unprocessed wood, "even though it has arguably a comparative advantage in producing and exporting it" (Peuker 1991).

Neither economic incentives nor local participation in protection of forests has played a significant role, though local participation has recently become more important. Rather, enforcement has relied on a "command-and-control" approach ${ }^{8}$ that requires a sizeable labor force, especially when the protected area is expanded into settled areas. Agencies charged with protection have small budgets, over $90 \%$ of which are dedicated to personnel and other fixed costs (USAID 1987). Funding is thus inadequate for operations and protected areas remain vulnerable.

Additionally, the majority of protected areas were established without any inventories or studies of their potential socio-economic impact on the populations living in or near them (Lutz and Daly 1990). Many areas earn no revenue, and, of those that do, none

7. The World Resources Institute reported deforestation rates of $2.6 \%$ for Costa Rica between 1980 and 1990; 2.1\% for El Salvador, and 1.9\% for Honduras (WRI 1994).

8. Command-and-control refers to the regulation and enforcement of human behaviors, in this case, as they relate to natural resources. An incentive approach is an alternative that relies on values or interests to influence the ways people relate to ecosystems. For example, people may conserve resources when conservation means sustainable extraction that protects household financial stability over the long-term. 
provide revenue-sharing incentives to local populations to help protect the forests. On the contrary, land acquisition within protected areas tends toward the opposite effect for reasons related directly to government policies. Announcement of protection induces land invasions because the government pays owners for their claims, and, because the government pays about twice as much for cleared land as it does for forest, claimants are highly motivated to clear their tracts (ibid.).

The government's attempts to protect and manage its forest resources have relied on forestry laws, trade policies, and creation of the protected area system discussed above. It also includes reforestation incentives, an initiative announced by President Calderón in 1990. Under the Forestry Law of 1990, the following principal fiscal incentives support reforestation (Peuker 1991):

1) Tax credits for all reforestation costs incurred, applicable over five years at rates of $50,20,15,10$ and 5 percent plus an additional credit equal to $10 \%-15 \%$ of reforestation costs.

2) Certificados de Abono Forestal (CAFs), which were introduced in the Forestry Law of 1986. CAFs are negotiable certificates worth up to $\phi 90,000 / \mathrm{ha}$, issued to persons reforesting land subjected to the régimen forestal ${ }^{9}$ and paid over five years at rates of 50 , $20,15,10$, and 5 percent. Small and medium-sized farms are entitled to receive advanced CAF payments. There are also special CAFs for insecticides. CAF recipients are granted exemptions of all taxes related to the purchase of vehicles and equipment after the fifth year of receipt of the CAFs.

3) Property tax exemptions for land submitted to the régimen forestal if the reforestation has been financed without any other subsidy.

4) Credit subsidies, including interest-free loans of up to $\phi 70,000 / \mathrm{ha}$ from the fondo forestal, financed by proceeds from debt-for-nature swaps. A Central Bank decision to allocate 5\% of the agricultural loans as soft loans to silviculture has not been implemented.

Reforestation has increased from an average of $10 \mathrm{~km} 2$ per year between 1980 and 1985, to an estimated $230 \mathrm{~km} 2$ in 1990 (ibid.). The sustainability of these efforts has been questioned, however, for a number of reasons. A 1983 study found that $56 \%$ of the area proposed for reforestation was under natural forest cover at the time, and $40 \%$ of the reforested areas were established on lands held speculatively and with no intention of commercial harvest. This explains in part the main limitation of the reforestation plan, its high costs which average $\phi 77,150 /$ ha. One conservative estimate shows that reforestation incentive costs exceeded the DGF budget by $150 \%$ in 1989 and 1990 (ibid.).

In light of these incentives, Ston Forestal's "reforestation" project becomes more than good public relations. It is also "good business" in the tradition of the United Fruit Company whose negotiating advantage decades earlier won major concessions from the Costa Rican government. According to a press release by Greenpeace (1993), Ston commissioned the Costa Rican Ministry of Public Transportation (MOPT) to build its

9. The régimen forestal is a concept central to the forestry laws of 1969, 1986, and 1990. This regime obliges any land holder to prepare a forest management plan, to be approved by the Dirección General Forestal (DGF), that specifies provisions for natural regeneration or reforestation. Any person, including all private landholders, who wishes to cut trees and use forest products must obtain permits from the DGF. In practice, it is only weakly enforced (Peuker 1991). 
chipper plant at Punta Estrellas, a move that would have freed Ston from regulations applied to private companies operating in Costa Rica. Oscar Fallas, executive director of AECO, the Association of Costa Rican Ecologists, correctly predicted the contract's rejection and pointed to the company's earlier business conduct, "This attempt by Stone Container is in line with their lack of respect for the regulations of Latin American countries and their desire to circumvent regulations that protect natural resources."

In spite of this observation, AECO's and Greenpeace's response to displacement of the chipper to Golfito's deep water harbor never matched their opposition to the Punta Estrellas site. In the summer of 1995, before ground had been broken, a lone priest sought signatures on a petition that would insist that the government carry out an environmental impact assessment before granting Ston's permit in Golfito.

Economists for the World Bank and the International Monetary Fund hope that structural adjustment policies will not only eliminate those distortions in the Costa Rican economy that produced near economic collapse, but also those that promote deforestation-subsidies to banana and sugar cane producers, for example. Yet the emphasis on exports has exacerbated rural poverty, up to $35 \%$ for the nation in 1995 , and the environmental degradation that results from poverty and extraction-based production (Meléndez-Howell 1998). Between 1980 and 1995, non-traditional exports expanded, the fiscal deficit worsened resulting in the dismantling of institutions, the country's external debt soared, and the distribution of income became more skewed. These conditions have only fortified the government's determination to increase exports, and so it has increased the country's environmental vulnerability to transient private investors. In 1987, for example, $83 \%$ of total banana production was exported after acreage had once again expanded beginning in 1986. This was after the gradual contraction of land devoted to banana production between 1973 and 1984, a period during which United Fruit began its conversion to oil palm plantations. This renewed expansion took place predominantly on the Atlantic Coast, from which United Fruit fled to Golfito in the early 1930s, and it amounted to 2,000 ha/year, much of which was brought into production at the expense of forest cover (FAO 1989).

\section{Conclusions}

[T] he company is not a philanthropic organization; it is not in the tropics for its health, but to make dividends for its stockholders (Kepner and Soothill 1935:345).

History shows Golfito's colonial ecological history to be situated at the intersection of the United Fruit Company's desires for profit and the Costa Rican government's desires for modernization at a time when national resources were scarce. This vulnerability led Costa Rican leaders to favor the powerful company's demands over Costa Rican needs, in exchange for railroad construction, and to make no provision in company contracts to mitigate ecological damage from company operations. Until quite recently, when Golfiteños have begun to talk about tourist dollars, contamination of Golfito's bay and landscape by United Fruit's cost- effective construction decisions were of little interest. Now, with the company gone, there is no source of revenue substantial enough to pay for cleanup, nor to manage increased pressure on the environment that results from national visitation to Golfito's new reduced-tax shopping mall. Based on environmental assessment of Ston's impact on the Golfo Dulce, the dumping of slurry into the bay can only further undermine the viability of the marine ecosystem. 
Costa Rican politicians, like other Central American politicians, facilitated private investments which proved profitable for companies, but onerous for the nation in ways that must now be weighed against the benefits of infrastructural development. They and their constituencies were anxious to stimulate agriculture and industry, and to enjoy the material rewards, so they facilitated exploitation of natural resources by transient corporations. This practice has only intensified as multinational companies search the planet for profitable opportunities. The World Bank estimated that between 1990 and 1996 , the private flow of money to the developing world had risen from $\$ 44$ billion to $\$ 244$ billion. Most of this investment, which the WorldWatch Institute says is much harder to track than public flows, underwrites mines, coal-fired power plants, logging projects, and other environmentally destructive forms of development (French 1997). All such investments, sustained contractually and by profit incentives, must be considered transitory. This fact and the nature of wage labor, as illustrated by the relationships among the Costa Rican government, the United Fruit Company, Golfiteños, and their environment, holds important implications for the sustainability of foreign corporate investment in extraction-based projects.

One can imagine a continuum of hypothetical relationships. At one end, direct dependence on natural resources associated with, for example, subsistence fishing, motivates extractors to protect the health and longevity of the environments on which they depend. The relationship is itself long-term, and the extractor may be culturally as well as economically rooted in the ecosystem (Gibson in press). At the other extreme, production practices and philosophies motivate extractors to mine resources efficiently, with little or no concern for either environmental health or longevity. The relationship between extractor and resource is, by design, short-term, and it is one from which the extractor can resign when the relationship ceases to be profitable (ibid.).

Wage laborers fall in between these extremes and vary in their tolerance for environmental degradation depending on such matters as consequences born by themselves and their families, and the availability of alternative income-earning opportunities. Capitalist enterprises, whose interests are contractual, defined primarily if not entirely by profit, and whose loyalties are to their stockholders, are without cultural rootedness in communities and environments, and cannot place the well-being of employees above "the bottom line." Thus they tend to fall at the transient extreme of the continuum. The implications of these relationships are seen in towns such as Golfito, Costa Rica, and in and around protected parks from which resident populations have been excluded.

Costa Rica's answer to Redclift (1992) then, to finesse the contradiction between conservation and capitalist development, is no answer at all for the long run. On the development side, towns like Golfito will remain economically vulnerable as long as development is measured by transient corporations' profit margins rather than sustainable satisfaction of basic human needs; and they will remain vulnerable to environmental degradation as long as environmental destruction is a cost of doing business that businesses don't have to pay. On the conservation side, the biodiversity of protected ecosystems, such as those associated with Corcovado and Esquinas National Parks, will remain at risk as long as the needs of resident populations for "development" are discounted by policy-makers caught between international lenders and environmentalists. In summary, development without conservation opens the door for transient corporate investors for whom development means short-term profits with little or no regard for either environmental costs or the basic needs of resident populations. Conservation without 
development exacerbates the poverty of resident peoples who may need protected resources to sustain themselves. It also ideologically legitimizes extraction activities outside of protected "green" areas. These decoupled agendas are not sustainable. They meet the short-term requirements of capital and play well among environmentalists in the political arena. But neither can be said to improve the well-being of people in the longrun, and that is the measure of sustainable development.

The history of Golfito is a colonial one, but, unlike its antecedents, the population of United Fruit's administrative center never had the opportunity to define human ecological relationships outside of proletarian relations with the company. What fishermen and farmers understand about marine and terrestrial health, that is, their fundamental dependence on it, Golfito's urban, wage-based population does not know in the same way. Today, for all but fishermen and piangueros, production of one's livelihood in Golfito means sales of value-added services and commodities rather than sale or consumption of raw materials and foods. The de-coupling of the ways families meet their basic needs from the health of their non-built environments, under conditions of economic desperation induced by corporate abandonment, pushes concerns for environmental conservation low on the list of household priorities. At the national level, the Costa Rican government's own economic desperation shapes its decision-making priorities as well. Environmental pressure from within and outside its borders must be acknowledged and addressed while simultaneously answering Costa Rican demands at every level, not only for security in basic needs, but for those modern lifestyles modelled by satellite.

Today, Golfiteños talk about the need to clean up the bay, about sewage treatment and solid waste disposal, but working and making ends meet present first order challenges. In their desire for adequate and reliable employment, they admire what United Fruit stood for; they aspire to "western" status marked by "western" things and demonstrate unrestrained enthusiasm for imported consumer goods, styles, and attitudes. These aspirations, coupled with a self-deprecating belief in their own incompetence, make Golfito prime real estate today for any company to act unrestrained for its own rewards. Since the mid-1930s, Golfiteños have been in training for just such an occasion.

To be sure, many things will determine how Golfiteños respond to the presence of Ston Forestal, not the least of which will be their declining material interests in the marine ecosystem as expatriates buy beach front property and commercial fishermen are driven out of business. Yet if they are to take any action at all, they must overcome beliefs in their impotence through acknowledgement of the resilience, creativity, and organizational skills already manifested in their daily lives. Indeed, a study carried out in the town in 1991 supports a finding that Golfiteño youth are more proactive than former company employees (M. Escalona, R. Gallardo, and R. Rice 1991). A 1995 study shows that the same can be said of newcomers to Golfito (J. Gibson forthcoming). What Golfiteños believe about themselves can become a compelling force for change or stasis, just as articulation of a particular view likely influenced the choice of Golfito for location of Ston Forestal's chipper.

But even if Golfiteños change their image locally and nationally, such that it reflects a proactive stance, human ecological conditions will not have changed. Golfito is caught in a negative feedback loop in which the ICT has money earmarked for tourism, but not for the cleanup necessary to attract tourists, even if the ICT paid more of the $25 \%$ so designated. Thus the development strategy solely dependent on promotion of consumption brings hundreds of thousands of Costa Ricans to Golfito every year to buy things, not to consume the aesthetics, leisure, and recreation of a healthy environment. 
Rather, their presence must continually degrade the ecosystem even as it increases household incomes. But because income goes up in the informal sector which, by definition, is neither taxed nor regulated, the municipality is still deprived of tax revenue which it might reasonably be expected to invest in, for example, a sewage treatment and solid waste disposal system.

Nor will national and international power relations have changed substantially. In spite of pro-ambiente billboards posted along Costa Rican highways, environmentalism is still largely driven by affluent North Americans and Europeans. Yet the cause of environmentalism converges with and shapes other phenomena: the globalization and "greening" of consumer ideologies and demands for developments that promise to fulfill consumer dreams, in the "north" with "ecotourism" and "neo-tribal" fetishes, in the "south" with designer clothing and electrodomesticos; and the "greening" of multinational corporate images while bio-prospector employees search for raw materials that now include human, plant, and animal gene codes. Thus when international lenders pressured Costa Rica to meet its obligations through governmental restructuring, austerity, and privatization, the country "greened" its image with billboards and ecotourism promotion while making environmental concessions to companies like Ston Forestal. Ston Forestal, having learned from its Honduran expulsion and Costa Rican refusal for a site on the Osa Peninsula, painted a new image of its gmelina plantations as part of a "reforestation" project!

The tensions inherent in these competing pressures was made plain at the Río Summit where the conflict between developing nations' needs to address poverty ran headlong into developed nations' and environmentalists' insistence that poor nations' ecosystems be protected from exploitation. In this light, Golfito's current situation begins to make sense as part of Costa Rica's strategy to balance its economic and ecological books. Sacrificing Golfito's environmental health generates economic development dollars for the nation, profits investors, and permits ecological conservation in other parts of the country-in this case, Parque Nacional Corcovado-where international tourism dollars can be maximized and the country's environmental reputation preserved.

Costa Rican environmentalists advocate the protection of remaining tropical rainforests, an effort that has precipitated policies and laws that have led many to describe Costa Rica as a model for conservation. Yet as long as the present international political and economic order prevails, we should not be surprised to find that Golfito is part of a larger pattern in which some ecosystems are thrown away in the interest of economic development and ecological conservation elsewhere. This is the essence of the contradiction between the goals of environmental conservation and those of development based on capitalism. One must choose between the two for a given location or community rather than truly reconciling them for local, regional, national, and global populations. In short, the familiar US pattern of locating landfills, chemical and nuclear waste, and highways in economically marginal and politically weak areas has become a global strategy in which poor regions within poor nations pay the price for others' environmental health, and profit-driven multinationals continue virtually unaffected by the local consequences of their economic activities.

The case study of the human and ecological costs of Costa Rican development, paid in part by Golfiteños, points to historical and contemporary similarities between the interests of global capitalist expansion and national and international environmental politics. Both constituencies always implicate local people yet remain indifferent to their basic needs. One must conclude first that if we desire sustainable development, the reconciliation will 
require more than the "greening" of corporate and governmental images. The logic of capitalist development requires that costs be minimized in order to maximize profits. This means that people become "labor," that is, "factors of production" (along with land, energy, raw materials, and other costs) that must be minimized. Simply stated, when the goal of development is maximum profit, it cannot simultaneously be the well-being of people. This requires as a minimum clean air and water as well as an income adequate to supply safe and sufficient food, housing, and healthcare, all of which impinge on profits.

Second, sustainable development must also mean more than trading off development in some places for conservation in others as in the creation of protected park systems. Local communities must be vested in the health of local environments without exacting a cost against their families. Only when basic human needs become a non-negotiable priority can one contemplate sustainable development, a concept that not only requires human and environmental health, but requires social justice and equity between and within nations so that national governments need not compete for unrestrained and uncontrolled development, nor bargain with human and environmental health to get it.

\section{References Cited}

Acuña, Victor Hugo and Iván Molina

1991 Historia Económica de Costa Rica. San José: Editorial Porvenir.

Anonymous

1994 Editorial. La Republica. Thursday, April 14: 12A.

Bozzoli, Marìa E. and Marcos Chàvez Castro

1987 Los Pescadores Pichorchos de Golfito. Ciencias Sociales 35:9-17.

Celis, Rafael

1998 Environmental Monitoring and Accounting in Costa Rica: An Overview. In

Costa Rica

1997 Cohort 6: Background Material for the Costa Rica Case Study.<http:// virtua.lead.org/lead/session/costarica/97/docs/chapter9.htm>

Cerdas Albertazzi, Ana Luisa

1993 El Surgimiento del Encloave Bananero en el Pacifico Sur. Revista de Historia, Julio-Diciembre, 28:117-59.

Cook, James

1992 New Growth. Forbes Magazine 149:107-10 (June 8).

Escalona, Miguel, Roberto Gallardo, and Robert A. Rice

1991 Agroecología: El Futuro de Latinoamérica. Organizacion para Estudios Tropicales. Universidad de Costa Rica.

FAO/World Bank

1989 Costa Rica Agricultural Sector Review, Report No. 47/89 CP-COS 7 SR. Rome, Italy.

Fallas, Carlos Luis

1970 Mamita Yunai. San Jose, Costa Rica: Editorial y Distribuidora Centroamericana.

Gibson, Jane W.

in press Linking Economic and Non-economic Values to Sustainable Use of a Wild Species: Florida's Alligator Management Program. Human Ecology. 
1998 An Essay on Sustainable Use: Harnessing the Market for Conservation and Development. Georgia Journal of Ecological Anthropology 2:85-95.

Greenpeace

1993 Costa Rican Government Thwarts Stone Container's Efforts to Build Wood Chip Mill in Osa Peninsula. Press release, December 22, 1993. San Francisco.

Hay, Diego

1983 The Southern Pacific Region of Costa Rica: Prospects for Development in the Wake of the Modern Industrial Plantation. unpublished manuscript. IFAM

1986 Cantones de Costa Rica: Datos Bàsicos. San Josè, Costa Rica.

Kepner, Charles David and Jay Soothill

1935 The Banana Empire: A Case Study of Economic Imperialism. New York: Russell and Russell.

Latin American Data Base

1997 EcoCentral: Central American Economy \& Sustainable Development. 2(4): January 30, 1997. Latin American Institute: University of New Mexico.

luckey, donna

1994 Planning in the Brunca Region of Costa Rica: Cultural Resources as the Sustaining Bridge between Population and the Natural Environment. unpublished manuscript.

Meléndez-Howell, Dennis

1998 The Costa Rican Economy. In Costa Rica 1997 - Cohort 6: Background Material for the Costa Rica Case Study. <http://virtua.lead.org/lead/session/ costarica/97/docs/chapter3.htm>

Miller, Wilfred T.

1995 Dos Años como Psicologo Voluntario en Golfito, Costa Rica. Ciencias Sociales 67:73-9, March.

MIRENEM (Ministerio de Recursos naturales, Energía y Minas) 1990 Plan de Acción Forestal para Costa Rica. San José, Costa Rica. March.

Peuker, Axel

1991 Public Policies and Deforestation in Costa Rica. World Bank. <http:// www.worldbank.org/html/lat/english/papers/env/cr_dfst.txt>

Salazar, Jorge Mario and Orlando Salazar

1991 Los Partidos Políticos en Costa Rica. San José, Costa Rica: EUNED.

Solís, Luis G.

1998 The Social and Political Evolution of Costa Rica: A Historical Appraisal. In Costa Rica 1997 - Cohort 6: Background Material for the Costa Rica Case Study. <http://virtual.lead.org/lead/session/costarica/97/docs/chapter1.htm>

Solórzano, R., R. Camino, R. Woodward, J. Tossi, V. Watson, A. Vásquez, C. Villalobos,

J. Jiménez, R. Reppeto, and W. Cruz

1991 Accounts Overdue: Natural Resource Depreciation in Costa Rica. Centro Científico Tropical and World Resources Institute. San José and Washington D.C.

Ston Forestal

1997a Welcome to Ston Forestal. http://www.nlbbs.com/ dc004/wsf.html

1997b Salama Farm/Nursery Operations. http://www.nlbbs.com/ dc004/salama.html

1997c Papermaking with Gmelina. http://www.nlbbs.com/ dc004/paperfib.html

1997d Gmelina Wood Characteristics. http://www.nlbbs.com/ dc004/

woodchar.html 
1997e Environmental \& Silviculture. http://www.nlbbs.com/ dc004/envrn.html

1997f Land Leasing Operations. http://www.nlbbs.com/ dc004/llo.html

$1997 \mathrm{~g}$ Chipping Operations. http://www.nlbbs.com/ dc004/chip.html\#chip facility

USAID

1987 Natural Resource Management in Costa Rica: A Strategy for USAID. San José, Costa Rica.

WCED (World Commission on Environment and Development)

1987 Our Common Future. Oxford: England. Oxford University Press

WRI (World Resources Institute)

1994 Regional Coordination in Central American Forest Policy. World Resources Institute. Washington, DC.

Zürcher de Carrillo, Joyce

1994 Informe Final y Recomendaciòn. Defensora Adjunta de los Habitantes. September 22.

\section{Abstract}

This paper takes a historical, political-ecological approach to understand the present economic and environmental condition of Golfito, Costa Rica. Contemporary problems result from the convergence of local human ecological relationships, local and national economic depression, national and global environmental politics, and international political and economic inequity. Powerful transient corporate investors exploit opportunities made available by vulnerable developing nations in a pattern of ecologically destructive "development" that may meet local and national needs for revenue; geographically distanced "conservation" areas protect "green" reputations but do not necessarily result in protection. The implication of this pattern is that sustainable development is discursively finessed, rather than practically reconciled.

key words: sustainable development, conservation, Costa Rica, Golfito, multinational corporations, political-ecology

\section{Résumé}

Cette contribution prend une approche historique et politico-écologique à fin d'avancer la compréhension de la condition environnementale de Golfito, Costa Rica. Les problèmes actuels peuvent être liés à une convergence des relations écologiques des habitants locaux, une dépression économique locale et nationale, la politique environnementale globale, et les inéquités économiques et politiques à l'échelle internationale. Les investisseurs á la fois puissants et intérimaires des grandes corporations exploitent les opportunités liées à la vulnérabilité des nations en voie de développement d'une manière déplorable. Le résultat est un développement qui répond aux besoins de revenu locaux et nationaux à court terme mais qui est destructif du point de vue écologique. L'existence des espaces vertes situées à des distances importantes protège la réputation "verte" mais généralement ne produit pas une conservation réelle. Les implications de ce modèle de développement soutenable est plutôt la création d'un discours raffiné qu'une réconciliation pratique.

Mots clefs: développement soutenable, conservation, Costa Rica, Golfito, corporations multinationales, écologie politique. 


\section{Resumen}

Este papel usa los análisis históricos, político-ecológicos para entender la actual condición económica y ambiental de la comunidad del Golfito en Costa Rica. Los problemas contemporáneos resultan de la convergencia entre los lazos de las poblaciones ecológicos locales, la depresión económica local y nacional, la política ambiental nacional y global, y la injusticia política y económica internacional. Los inversionistas corporativos transitorios de gran poder explotan las oportunidades hechas disponibles por países en desarrollo vulnerables en un modelo del " desarrollo ecológico destructivo " que pueda resolver las necesidades de ingreso locales y nacionales ; las áreas geográficamente distanciadas de la " conservación " protegen reputaciones del " verde " pero no dan lugar necesariamente a la protección. La implicación de este modelo es que es uno en que el desarrollo sostenible es más manipulado discursivamente que reconciliado prácticamente. palabras claves: desarrollo sostenible, conservación, Costa Rica, Golfito, corporaciones multinacionales, ecología política. 